\title{
Clinician, upgrade thyself
}

$\mathrm{A}$

fter years of being assailed for failing to develop systems that promote meaningful use of electronic health data by physicians and patients, Canada Health Infoway has launched an education campaign aimed at persuading clinicians to make the leap into the world of wired medicine.

Although critics assail the Knowing is Better than not Knowing clinician education campaign as little more than political fodder aimed at convincing the federal government to ante up more billions toward the development of a national electronic health infrastructure, proponents argue it's needed to help overcome physician reluctance or resistance to adopting electronic medical records (EMRs).

The initiative should also serve to promote the establishment of a national system that's capable of more readily sharing a patient's health information between clinicians, whenever that is needed, proponents add.

"Physicians are using [electronic health records] and there is a lot of benefit to them. What Canada Health Infoway is aiming to do is in various ways link them together so that the information will flow smoothly between clinicians of various sorts," says Dr. Michael Golbey, chair of the board of the Canadian Medical Association and chair of Clinical Council Infoway. "The major benefit is absolutely getting the appropriate clinical information about the right patient at the right time in a timely manner."

But others aren't convinced that the campaign is an indicator that Infoway is actually rebooting its strategy in the direction of achieving health improvements through the use of electronic technologies.

'It's more of an effort to persuade the government to open its vaults than one to promote meaningful use at the clinician level," says Dr. Karim Keshavjee, CEO of InfoClin, which helps physicians implement medical information technology systems in their practices,

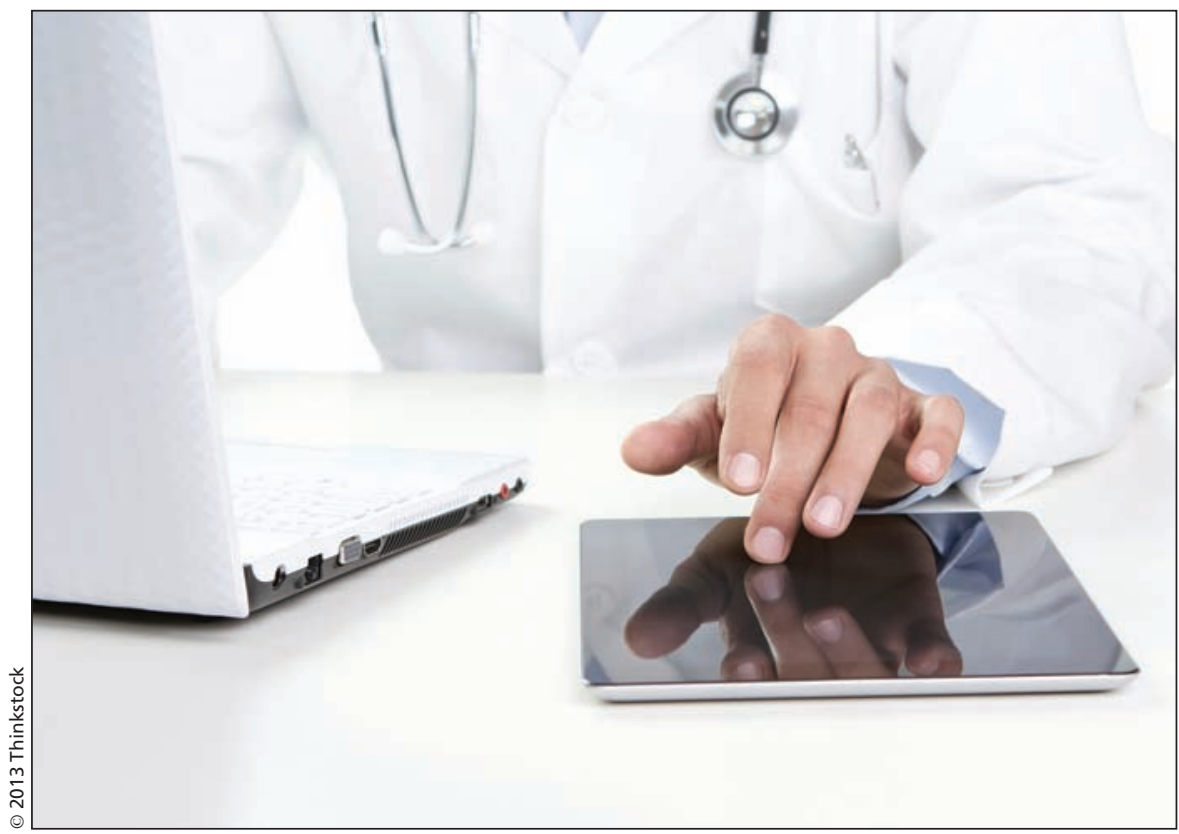

Canada Health Infoway considers clinicians to be among the biggest obstacles to wider use of electronic medical records.

and an associate member of the Centre for Evaluation of Medicines, an independent academic research institute affiliated with McMaster University in Hamilton, Ontario. "If they're not able to demonstrate to their funders what the value is, then the government doesn't give them money."

Infoway has long been criticized for favouring the development of massive centralized data systems over measures to promote meaningful use of electronic health data by physicians and patients (www.cmaj.ca/lookup/doi/10 .1503/cmaj.109-3744 and www.cmaj.ca /lookup/doi/10.1503/cmaj.109-3860 and www.cmaj.ca/lookup/doi/10.1503/cmaj .109-3242). Progress has been so dismal and outlays so wasted that some observers have urged that an independent national "watchdog" be appointed to assess and oversee federal e-health efforts (www.cmaj.ca/lookup/doi/10 .1503/cmaj.109-3783).

Infoway CEO Richard Alvarez recently indicated that the agency is gearing for a reset and will focus its future efforts on the development of "consumer health systems" that allow for remote patient monitoring, e-scheduling of appointments, e-prescribing and electronic patient-client encounters, while developing "new models of care" that promote patient safety through such means as greater use of e-referrals and the provision of e-summaries of patient information upon discharge from hospitals (www.cmaj.ca/lookup/doi/10.1503 /cmaj.109-4219).

Alvarez also argued that clinicians are among the biggest obstacles to wider use of EMRs. But the new campaign isn't an attempt to force change on physicians, so much as it is the provision of tools to make that decision easier, says Dr. Jennifer Zelmer, senior vice president of clinical adoption and innovation at Infoway. "We basically started down this path because we're supporting a number of peer leader groups and have clinical reference groups and clinician-in-training programs, and folks were coming to us and saying to us that it would be really helpful to have some additional resources for the works that they were 
doing with their colleagues, other clinicians and also with clinicians in training in med school and nursing school and pharmacy school and so on," she says.

Zelmer says the campaign primarily features a website that provides physicians with online resources, such as tutorials, to better understand how EMRs could benefit their practice (https://www .infoway-inforoute.ca/index.php/progress -in-canada/knowing-is-better).

The slow rate at which Canadian physicians have adopted electronic systems may be functions of age, cost, privacy concerns or even antipathy to change, Golbey says. "There's still resistance, or reluctance, I should say, probably particularly from older physicians, those that are getting fairly close to retirement who are concerned about the cost and the effort and energy that's required to install these systems. So not everybody's on board."

But EMRs save time, money and even lives, adds Golbey, who, at the age of 64, installed a system in his Kelowna, British Columbia-based office two years ago. "It continues to amaze me.
Now that we've changed, I get everything coming to me electronically now, probably $99 \%$ of my data comes to me electronically and automatically. Sometimes, I get results, where a patient has been to the lab, before they even get home and it just astonishes the patient when they get home and there is a message from my office saying: 'Please call. We've got a result for you.' So it's just an entirely different way of doing business and practising medicine. It's remarkable."

Golbey also argues that physicians will soon begin to reap the rewards of Infoway's decision to concentrate on the development of a national architecture before moving along to measures designed to promote clinical use of EMRs. "The backbone is what Infoway is providing," he says. "Infoway was certainly frustrating to physicians and for a long time there was a lot of money put into it and we didn't see any immediate benefits. But I really believe that was needed to build the backbone and we're certainly beginning to see the benefits now."

Keshavjee isn't as convinced. He argues that there's no legitimate explanation for the duration of time that it has taken Infoway to focus its attention on clinical use of EMRs, and that a clinical education campaign is hardly an indicator that Infoway has abandoned its fondness for "big projects" in favour of measures that integrate EMRs with the electronic systems of hospitals, labs, pharmacies and other elements of the health system.

Moreover, there is no evidence that the 385 projects that Infoway has previously supported to ostensibly promote clinician use of EMRs have had any impact on the health system, he adds. "385 projects should show huge impact. It should be visible to us. It's not. Why is it not visible? It's not visible because the projects are not doing that well. But Infoway can't say that, so what they do is they come out with a TV campaign that is visible to politicians and to the public and which the public gets excited about hopefully, and they can then tell their politicians that." — Adam Miller, CMAJ

CMAJ 2013. DOI:10.1503/cmaj.109-4339 